\title{
Five-year risk of HIV diagnosis subsequent to I 47 hospital-based indicator diseases: a Danish nationwide population-based cohort study [Erratum]
}

\author{
Omland LH, Legarth R, Ahlström MG, et al. Clin Epidemiol. \\ 2016;8:333-340.
}

On page 338, Table 1 was referenced in error under the heading "Patient categories with a particularly high FYRHD". The incorrect sentence read as "The ten combinations of indicator diseases, age, and sex with the highest FYRDH among individuals of Danish origin, as well as the ten indicator diseases with the highest FYRHD among individuals of African origin, are shown in Table 1."

The correct sentence should read "The ten combinations of indicator diseases, age, and sex with the highest FYRHD among individuals of Danish origin, as well as the ten indicator diseases with the highest FYRHD among individuals of African origin, are shown in Table 2."
Table 2 was missed from being included in the paper and is as follows:

Table 2 Ten combinations of indicator disease, sex and age in the Danish population and the African population with the highest FYRHD

\begin{tabular}{|c|c|c|}
\hline Indicator disease & Population & FYRHD $(95 \% \mathrm{Cl})$ \\
\hline Lymphoma & African & 22.105 (6.397-43.665) \\
\hline Thrombocytopenia & African & I8.000 (8.799-29.824) \\
\hline Herpes zoster & African & $17.89 \mid(|0.302-27.17|)$ \\
\hline Pneumococcal pneumonia & African & $15.000(3.560-33.991)$ \\
\hline Syphilis & African & II.364 (4.105-22.735) \\
\hline $\begin{array}{l}\text { Viral meningitis and } \\
\text { encephalitis }\end{array}$ & African & $10.256(3.199-22.169)$ \\
\hline Other CNS infections & African & 8.511 (2.679-18.69I) \\
\hline Mononucleosis & African & $6.250(0.362-25.479)$ \\
\hline Candida infection & African & $5.000(1.610-11.379)$ \\
\hline $\begin{array}{l}\text { Lung abscess/empyema } \\
\text { without pneumonia }\end{array}$ & African & $4.762(0.304-20.204)$ \\
\hline Syphilis & Male 30 years & I3.376 (7.465-2|.024) \\
\hline Hepatitis A & Male 20 years & 7.805 (3.417-14.566) \\
\hline Syphilis & Male 50 years & $7.038(2.838-13.844)$ \\
\hline Syphilis & Male 40 years & $6.101(1.943-13.740)$ \\
\hline Hepatitis A & Male 30 years & $5.464(2.403-10.369)$ \\
\hline Endocarditis & Female 20 years & $4.774(1.763-10.111)$ \\
\hline Candida infection & Male 30 years & $4.009(2.463-6.121)$ \\
\hline Syphilis & Male 20 years & $4.000(1.298-9.209)$ \\
\hline Other STIs & Male 30 years & $3.997(2.370-6.266)$ \\
\hline Non 'A' viral hepatitis & Male 30 years & $3.55 I(2.8 I I-4.4 I 7)$ \\
\hline
\end{tabular}

Abbreviations: FYRHD, 5-year risk of an HIV diagnosis; $\mathrm{Cl}$, confidence interval; CNS, central nervous system; STIs, sexually transmitted infections.
Clinical Epidemiology

\section{Publish your work in this journal}

Clinical Epidemiology is an international, peer-reviewed, open access, online journal focusing on disease and drug epidemiology, identification of risk factors and screening procedures to develop optimal preventative initiatives and programs. Specific topics include: diagnosis, prognosis, treatment, screening, prevention, risk factor modification,

\section{Dovepress}

systematic reviews, risk and safety of medical interventions, epidemiology and biostatistical methods, and evaluation of guidelines, translational medicine, health policies and economic evaluations. The manuscript management system is completely online and includes a very quick and fair peer-review system, which is all easy to use. 